\title{
Properties of particleboards manufactured from bamboo (Dendrocalamus asper)
}

\author{
Flávia Maria Silva Brito ${ }^{1}\left[\right.$, Geraldo Bortoletto Júnior ${ }^{1}[0$ \\ 1 Universidade de São Paulo, Escola Superior de Agricultura Luiz de Queiroz, Piracicaba-SP, Brazil. E-mail: faengflorestal@gmail.com; gbjunior@usp.br
}

ABSTRACT: Bamboo is a source of industrial raw material with wide geographical distribution. Brazil has good soil and climate conditions for its cultivation, in addition to existing reserves. Advantages of bamboo include: versatility, fast growth and good strength properties. One way of using this material would be as a raw material for manufacturing particleboards. Within this context, this article addresses an evaluation of the physical and mechanical properties of particleboards manufactured from bamboo particles (Dendrocalamus asper (Schult f.). Backer ex Heyne. Particles with 0.50 and $0.85 \mathrm{~mm}$ granulometry and two conditions (control and treatment by immersion in hot water $\left(70 \pm 5^{\circ} \mathrm{C}\right.$ ) for two hours) were used. Twelve homogeneous particleboards bonded with urea-formaldehyde adhesive with $10 \%$ solids were manufactured and the predetermined nominal density for all panels was $650 \mathrm{~kg} \mathrm{~m}^{-3}$. The properties analyzed were: water absorption, swelling and non-return rate in thickness, density profile, rupture modulus, elastic modulus, screw withdrawal and internal adhesion. Panels consisting of $0.50 \mathrm{~mm}$ granulometry showed higher water absorption rates, while panels made of particles treated with hot water and $0.85 \mathrm{~mm}$ granulometry showed higher swelling rates and non-return thickness. The panels made of treated particles showed higher density profile values in both layers of the panels. The granulometry did not influence the mechanical properties of the panels, and those with treated particles exhibited significant performance for the surface and top screw withdrawal properties, and internal adhesion. This last mentioned property reached the minimum value required by the standard. The results showed that it is feasible to use bamboo to manufacture particleboards, but it is necessary to adjust some variables such as nominal density, pressing parameters, adhesive content or the inclusion of a less dense material in the composition of the panels.

Key words: granulometry, hot-water treatment, particle classification, physical and mechanical properties

\section{Propriedades de painéis aglomerados produzidos com partículas de bambu (Dendrocalamus asper)}

RESUMO: O bamboo é uma fonte de matéria prima industrial de ampla distribuição geográfica. O Brasil dispõe de boas condições edafoclimáticas para o cultivo deste material, além das reservas já existentes. As vantagens do bambu incluem: versatilidade, rápido crescimento e boas propriedades de resistência. Uma das formas de aproveitamento deste material seria como matéria prima para fabricação de painéis aglomerados. Dentro deste contexto o trabalho teve como objetivo avaliar as propriedades físicas e mecânicas de painéis produzidos com partículas de bambu (Dendrocalamus asper (Schult f.) Backer ex Heyne. Partículas com granulometria de 0,50 e $0,85 \mathrm{~mm}$ e duas condições (controle e tratamento por imersão em água quente $\left(70 \pm 5^{\circ} \mathrm{C}\right)$ por duas horas) foram utilizadas. Fabricaram-se doze painéis homogêneos de partículas, colados com adesivo de ureia-formaldeído, com $10 \%$ de sólidos e densidade nominal pré-estabelecida de $650 \mathrm{~kg} \mathrm{~m}^{-3}$. As propriedades analisadas foram: absorção de água, taxa de inchamento e não-retorno na espessura, perfil de densidade, módulo de ruptura, módulo de elasticidade, arrancamento do parafuso e adesão interna. Painéis constituídos com granulometria 0,50 mm evidenciaram maiores taxas de absorção de água, enquanto painéis constituídos de partículas tratadas com água quente e granulometria $0,85 \mathrm{~mm}$ mostraram maiores taxas de inchamento e taxa de não retorno em espessura. Os painéis fabricados de partículas tratadas apresentaram valores maiores de perfil de densidade para ambas as camadas dos painéis. A granulometria das partículas não influenciou as propriedades mecânicas dos painéis, e aqueles com partículas tratadas exibiram desempenho significativo para as propriedades de arrancamento de parafuso de superfície, topo e adesão interna. Esta última propriedade mencionada atingiu o valor mínimo requerido pela norma utilizada. Os resultados mostraram que é viável a utilização de bambu na fabricação de painéis de partículas, mas é necessário ajustar algumas variáveis, como densidade nominal, parâmetros de prensagem, teor de adesivo ou a inclusão de um material menos denso na composição dos painéis. 


\section{Introduction}

Brazil is one of the ten largest producers of wood panels in the world. Production in 2018 was 7.9 million $\mathrm{m}^{3}$ of panels (IBÁ, 2018). The percentage is still below the production possibilities of Brazilian industries, considering the country's timber potential and installed technologies (Nogueira et al., 2018). The main industries of agglomerated panels which supply the main furniture centers are in the South and Southeast Regions, located in the states of São Paulo, Minas Gerais, Paraná, Santa Catarina and Rio Grande do Sul (Iwakiri et al., 2016).

The main raw material used in manufacturing particleboards in the past 80 years was wood, but the demand results in a lack of supply in the market (Klímek et al., 2018). Therefore, it is necessary to look for alternative sources of materials which avoid pressure on natural ecosystems and open new challenges for technology development and product innovation (Barbirato et al., 2014).

Mesquita et al. (2018) mention some materials which are sources of the great diversity of lignocellulosic residues produced by the Brazilian agroindustry and can be used such as corn cobs, sugarcane bagasse, husks (oats, rice, coffee, coconut, beans and peanuts), and bamboo, among others. Bamboo is a monocotyledonous angiosperm that spans 119 genera with 1482 species and is classified into three tribes: Arundinarieae, Bambuseae and Olyreae (Clark et al., 2015). This material has been used for industrial applications since the $20^{\text {th }}$ century, especially as a raw material for wood-based composites such as chipboards, medium density fiberboards, hardboards, plywood, particle oriented paneling, plywood, laminate, glued bamboo, panels agglomerated with inorganic materials (i.e. cement), and plastic and wood composites (Chaowana, 2013).

An important aspect about bamboo particleboard production is the ease of cultivating this grass in practically all regions in Brazil and with short crop cycles, which provides a large volume of raw material for producing the panels (Negrão et al., 2014). It is used for construction in various parts of the world because it is easily managed and has good physical and mechanical properties (Sanquetta et al., 2017). In comparison with natural composites, bamboo has high rigidity and strength due to its good mechanical properties and low density (Fazita et al., 2016).

The density varies in the stems and mainly depends on the density of the vascular bundles. This property usually increases from the inside to the outside, and from the bottom to the top in the stalk. The density of the inner layers of the culm wall increases with stem growth and wall thickness, while the outer layers only slightly change (Anokye et al., 2016). This is an important physical property because it evaluates the weight of the structures and has a relationship between mechanical properties such as tensile strength, which may indicate possibilities of direct application or in conjunction with conventional building materials, without losing the intended final strength (Beraldo \& Azzini, 2004). According to
Berndsen et al. (2010) and Anokye et al. (2016), density values for different bamboo species can range from 400 to $900 \mathrm{~kg} \cdot \mathrm{m}^{-3}$.

The material density for panel production is very important because it is directly related to all other properties, in addition to influencing the panel compaction ratio which is calculated by dividing the apparent density of the panel by the apparent density of the lignocellulosic material. This value should be in the ideal range of 1.3 to 1.6 (Maloney, 1993). The compaction ratio tends to be lower when the material is denser, which may reflect the final quality of the panel.

The vertical density profile reflects density distribution across the panel thickness. The face density is typically greater than the core density, which produces an " $\mathrm{M}$ " letter profile. This profile is related to the pressing process and is important for panel quality assessment for various uses (Cai et al., 2006). $X$-ray scanning technology has good potential to provide a reliable and efficient continuous panel evaluation process (Wang et al., 2006).

Another highlight for particleboard production is particle size which can influence the properties of the panels. Some studies have already analyzed the influence of this factor on the quality of panels such as: Torrell et al. (2013), Lias et al. (2014) and Farrokhpayam et al. (2016). Studies by Azambuja et al. (2015) and Bazzetto et al. (2019) who analyzed the effect of bamboo particle size on the properties of the panels are also noteworthy.

Research has already been conducted with the objective of producing experimental panels with bamboo associated or not with other lignocellulosic materials or varying some production parameter (Valarelli et al., 2013; Valarelli et al., 2014; Zaia et al., 2015, Dinhane et al., 2015; Melo et al., 2015; Morais et al., 2015; Almeida et al., 2017; Abdulkareem \& Adeniyi, 2017). The species Dendrocalamus asper (Schult f.) Backer ex Heyne was used for the present experiment due to its good resistance properties. It is native to Southeast Asia and probably introduced to Brazil by the Portuguese colonizers. It has large clumps up to $30 \mathrm{~m}$ high and the stem diameter at the base can reach more than $30 \mathrm{~cm}$ (Tombolato et al., 2012). It can be used for structures of all sizes and to manufacture glued laminated bamboo.

In this context, this work aimed to evaluate the physical and mechanical properties of panels made with bamboo particles of the Dendrocalamus asper (Schult f.) Backer ex Heyne species.

\section{Materials and Methods}

\section{Material origin}

Dendrocalamus asper (Schult f.) Backer ex Heyne species was selected due to its good mechanical resistance properties and availability. It was collected at the Unit of Research and Development (URD) at the Institute of Agronomy of Campinas (IAC) in Tatuí, São Paulo State, Brazil. Stems older than three years were used. The parameters for recognizing maturity were signs of stains, absence of sheath and branching in the culm. 
A saw and a large knife were used for cutting the stems and pruning, respectively. The stems were divided into $2 \mathrm{~m}$-sections for easier transport of the material and the parts with lower than $5 \mathrm{~cm}$ of diameter (apexes) were discarded (Brito et al., 2018).

Mechanical processing of the bamboo and obtaining the particles

The culms were cut in a circular saw in the longitudinal direction to obtain the splinters, which were then processed in a planer thicknesser that removed the internal layer which is starch-rich, and the external layer (cutin-containing peel), which is permeable. The splinters were transformed into chips by a band saw.

The chips were exposed to air for natural drying until they had reached approximately $18 \%$ moisture. They were then placed in a greenhouse with forced air circulation and kept at $70 \pm 2{ }^{\circ} \mathrm{C}$ until reaching an average of $10 \%$ moisture content, and transformed into particles in a Willey-type mill with a $4 \mathrm{~mm}$-opening mesh sieve.

\section{Basic density and granulometric classification}

Ten samples of bamboo chips were selected for obtaining the basic density, being determined according to the Brazilian Standard NBR 11941 (ABNT, 2003).

The particles were classified in a set of sieves of 2.00, 0.85 and $0.50 \mathrm{~mm}$ meshes and a collection tray. First, 1000 $g$ particles were placed on the higher sieve with larger openings. The particles that remained in the different meshes of the set and the collector were weighed after $10 \mathrm{~min}$. The mass obtained was changed into percentage (\%) according to the initial number of particles placed on the first sieve. The particles retained in the 0.85 and $0.50 \mathrm{~mm}$-meshes were used in the particleboards due to their better morphology and accommodation in the mattress.

\section{Treatment of the particles by immersion in hot water}

The particles were treated in hot water to remove the soluble materials. A 5/16"'-iron-bar structure of $63 \times 30 \times$ $83 \mathrm{~cm}$ (width $x$ height $x$ length) was built for the treatment and coated with a double sombrite layer netting to avoid dispersing the material in the tank.

They were placed inside the structure and immersed in hot water $\left(70 \pm 5^{\circ} \mathrm{C}\right)$ for $2 \mathrm{~h}$ in a metallic tank with $1.2 \times 0.70 \mathrm{x}$ $1.5 \mathrm{~m}$ (width $\mathrm{x}$ height $\mathrm{x}$ length) dimensions (Figure 1).

After treatment in hot water, the particles were removed from the box and washed with running water. They were then arranged on a canvas for outdoor drying and the process was finished in a greenhouse until reaching a moisture content between 3 and $4 \%$.

Manufacture of the particleboards and obtaining the samples

The pre-established dimensions of the boards were 650 $\mathrm{kg} \cdot \mathrm{m}^{-3}$ nominal density, $15.70 \mathrm{~mm}$ nominal thickness and $10 \%$ solid content, according to the dry mass of the particles. The urea-formaldehyde (UF) adhesive used was provided by a

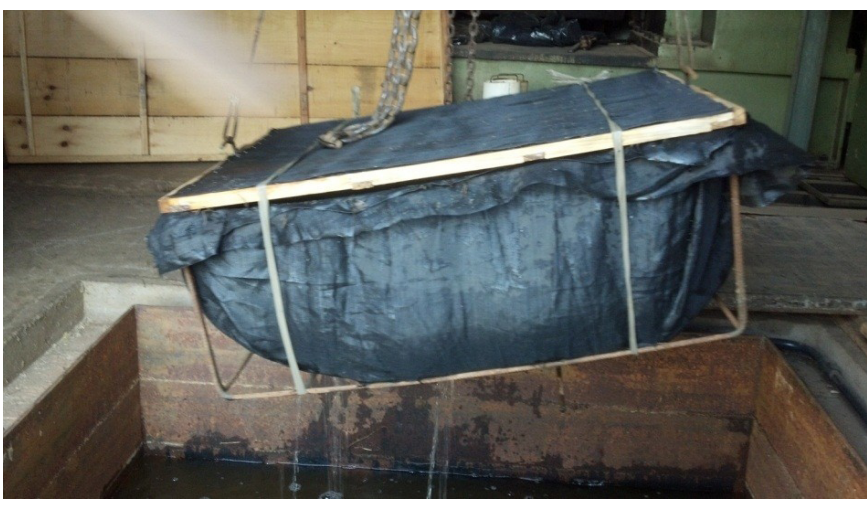

Source: Brito (2018).

Figure 1. Treatment of particles in hot water.

company from Rio Claro, São Paulo state. It contained $64.16 \%$ solid content and presented $1.27 \mathrm{~g} . \mathrm{cm}^{-3}$ density and $7.88 \mathrm{pH}$.

A $5 \%$ solids ammonia sulphate solution (catalyst) was incorporated into the adhesive and the mixture was homogenized and sprinkled on the particles through a spinning drum-type warp slasher . A $1.0 \%$ solids paraffin emulsion was then added. The materials were mixed for $5 \mathrm{~min}$ in a $12 \mathrm{rpm}$ drum for gluing the particles.

The particles were distributed in a $40 \times 40 \mathrm{~cm}$ wooden box and pre-pressed into the initial shape of the mattress, which was then removed and subjected to hot pressing. The pressing parameters were $35 \mathrm{kgf. \textrm {cm } ^ { - 2 }}$ pressure, 180 oc temperature and 10 minutes pressing time. The panels were removed from the press and remained in the vertical position until they reached ambient temperature. The boards were acclimatized at $22 \pm 2 \circ \mathrm{C}$ temperature and $65 \pm 5 \%$ relative humidity (Figure 2). After mass stabilization, they were squared to remove the samples according to the designations of NBR 14810 (ABNT, 2006).

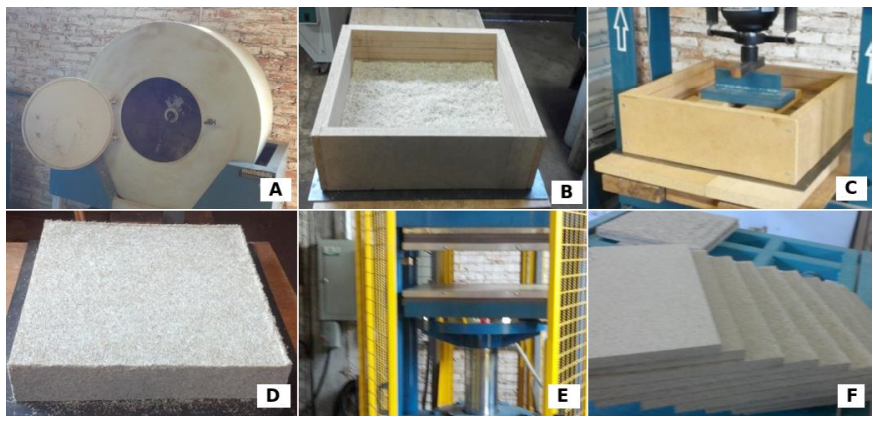

Source: Brito (2018).

Figure 2. Panel manufacture: (A) Warp slasher; (B) Mattress forming; (C) Manual hydraulic press; (D) Particle Mattress; (E) Motorized hydraulic press; (F) Finished particleboards.

\section{Physical and mechanical properties of particleboards}

The physical and mechanical properties were determined according to the designations of NBR 14810 (ABNT, 2006). The properties were as follows: apparent density (AD), water absorption after 2 hours immersion in water (WA2h), water absorption after 24 hours immersion in water (WA24h), thickness swelling after 2 hours of immersion in water (TS2h and TS24h), non-recoverable (NRT), modulus of rupture 
(MoR) and modulus of elasticity (MoE) to static bending, internal adhesion (IA) and panel surface resistance (SSW) and top resistance (TSW) to screw withdrawal.

We used a QMS QDP-01X model X-ray densitometer of $10-50 \mathrm{KV}, 1.5 \mathrm{ma}$ current and 180 and $90 \mu \mathrm{m}$ initial beam and final collimation for the density profile analysis, while the procedures described by Surdi et al. (2014) were adopted for the experiments.

The specific gravity parameters in graph 02 were established for analyzing the density profile of the outer layer and the central layer. A $2 \mathrm{~mm}$-band was taken from each end of the particleboard to determine the outer layer values and the panel core values were used to determine the apparent specific gravity of the central layer.

\section{Experimental design and analysis of the results}

The entirely randomized delineation of $2 \times 2$ factorial arrangement, 2 granulometry levels $(0.85 \mathrm{~mm}$ and $0.5 \mathrm{~mm}$ ) and treatment of the particles (non-treated and treated in water) (Table 1) were adopted for manufacturing the particleboards. Three boards were manufactured for each treatment, totaling 12 experimental units.

An analysis of variance was performed considering significant by the F-test $(p<0.05)$. Lilliefors and Cochran tests checked the normality of the data and homogeneity of the variances, respectively. The physical and mechanical test results were compared with those established by NBR 14810 (ABNT, 2006) for the characterization of particleboards.

Table 1. Performed experimental treatments.

\begin{tabular}{ccc}
\hline Treatment & $\begin{array}{c}\text { Granulometry } \\
(\mathbf{m m})\end{array}$ & $\begin{array}{c}\text { Particle } \\
\text { conditions }\end{array}$ \\
\hline T1 & 0.50 & Dried in an oven \\
T2 & 0.50 & Treated in hot water \\
T3 & 0.85 & Dried in an oven \\
T4 & 0.85 & Treated in hot water \\
\hline
\end{tabular}

\section{Results and Discussion}

\section{Granulometry, basic density and compaction ratio}

The retention values of bamboo particles are influenced by the type, model and mesh of the mill used for chip milling. The fraction used to manufacture the panels $(0.85 \mathrm{~mm}$ and 0.50 $\mathrm{mm}$ ) totaled a percentage corresponding to $62.19 \%$ (Table
2). This fraction was selected according to the morphology considered adequate for producing the panels.

The lowest proportion of particles was retained in the $2.0 \mathrm{~mm}$-opening sieve and the highest proportion retained in the collector (Table 2 ) was classified as "fine" $(<0.50 \mathrm{~mm})$ and discarded. Using thin particles guarantees a better finish to the surface of the panel, mainly aiming at improving the conditions of applying revetment materials. On the other hand, a high percentage of thin particles increases resin consumption and affects the panel quality because it reduces internal adherence between the internal and external layers of the panel (for layered panels) (Azambuja et al., 2015).

The basic density of the bamboo chips was $530 \mathrm{~kg} \cdot \mathrm{m}^{-3}$; a value corresponding to that found by Bazzetto et al. (2019), and lower than that cited by Santos et al. (2016), who obtained 600 $\mathrm{kg} \cdot \mathrm{m}^{-3}$, but between the $400 \mathrm{~kg} \cdot \mathrm{m}^{-3}$ and $900 \mathrm{~kg} \cdot \mathrm{m}^{-3}$ reported by Berndsen et al. (2010) and Anokye et al. (2016). Therefore, the nominal compaction ratio obtained was $1.23(650 / 530=1.23)$ and the effective compaction was $1.13(600 / 530=1.13)$. The result is below the range of ideal values for the compaction ratio, i.e. 1.3 and 1.6 (Moslemi, 1974). However, such a range was established for wooden boards.

Table 2. Granulometry distribution of bamboo particles.

\begin{tabular}{cc}
\hline Sieves $(\mathrm{mm})$ & Retention (\%) \\
\hline 2.00 & $0.54(0.12)$ \\
0.85 & $35.84(0.73)$ \\
0.50 & $26.35(0.35)$ \\
$<0.50$ & $37.34(0.43)$ \\
\hline Classification of $1000 \mathrm{~g}$ of bamboo particles. Values in parentheses are standard
\end{tabular}
deviations.

\section{Physical properties of the particleboards}

The apparent density showed no significant differences between the factors and the interactions (Table 3 ). The average values of the particleboards were lower than what is established $\left(650 \mathrm{~kg} \cdot \mathrm{m}^{-3}\right)$. This trend was also observed by Valarelli et al. (2013) and Bazzetto et al. (2019), as well as by Melo et al. (2015), who observed a loss of adhesive and paraffin during panel manufacturing due to adhesion on the edges of the sizing machine and differences in the specific mass and moisture content of the particles used to make the panels. The particleboards showed average density (Table 3) of 550 to $750 \mathrm{~kg} \cdot \mathrm{m}^{-3}$, which is in agreement with NBR 14810 (ABNT, 2006). Density is a quality indicator

Table 3. Mean values of apparent density (AD), moisture content (MC), water absorption in 2 hours (WA2H), water absorption in 24 hours (WA24H), thickness swelling in 2 hours (TS2H), thickness swelling in 24 hours (TS24H) and non-recoverable tax (NRT) of particleboard panels.

\begin{tabular}{|c|c|c|c|c|c|c|c|}
\hline \multirow{2}{*}{ Treatments } & \multirow{2}{*}{$\begin{array}{c}A D^{N S} \\
\left(\mathrm{~kg} \mathrm{~m}^{-3}\right)\end{array}$} & MC & WA2H*** & WA24H* & TS2H* & TS24H** & NTS** \\
\hline & & \multicolumn{6}{|c|}{ (\%) } \\
\hline $\mathrm{T} 1$ & 590 & 9.14 & 76.52 & 92.79 & 9.03 & 10.65 & 5.16 \\
\hline $\mathrm{T} 2$ & 580 & 9.45 & 64.78 & 89.58 & 15.49 & 19.49 & 12.45 \\
\hline T4 & 580 & 9.32 & 63.34 & 84.41 & 16.05 & 18.60 & 13.23 \\
\hline Overall mean & 580 & 9.30 & 66.72 & 86.50 & 12.77 & 15.72 & 9.52 \\
\hline
\end{tabular}

CV: coefficient of variation; ${ }^{\text {NS }}$ Not significant; *A significant factor; ${ }^{* *}$ Two significant factors; $* * *$ interaction between factors. 
since it is related to all the other characteristics of the particleboards.

The moisture content of the particleboards (Table 3 ) is in the $5 \%$-to- $11 \%$ range established by NBR 14810 (ABNT, 2006) for commercialization.

The water absorption showed a statistical difference between the factors and interaction (Table 3 ). Table 4 shows a comparison of the averages for WA2h.

The particleboards manufactured with control particles of $0.85 \mathrm{~mm}$-granulometry showed better performance since they absorbed less water in comparison with the others due to the larger availability of the adhesive for a smaller superficial area of particles in comparison with the $0.50 \mathrm{~mm}$-granulometry. As a result, larger surfaces were coated, empty spaces were reduced and water entry was hindered.

The water absorption values in $24 \mathrm{~h}$ showed a statistical difference for granulometry, however no significance was detected for the particle condition and interaction among the factors (Table 3). Table 5 shows a comparison of the averages.

The particleboards manufactured with particles of $0.50 \mathrm{~mm}$-granulometry showed a higher water-absorption rate than those manufactured with $0.85 \mathrm{~mm}$-granulometry particles. The behavior of the WA24h property was similar to that of WA2h. The reduction in the absorption rate for particleboards with $0.85 \mathrm{~mm}$-particles could be due to the higher relative availability of the adhesive distributed for the same mass of particles caused by the smallest specific superficial area, which might have hampered the water absorption process. NBR 14810 (ABNT, 2006), which was in force until 2013, did not stipulate values for this property.

The results of the present study were superior to the values obtained in the literature. Valarelli et al. (2013) worked with bamboo particleboards (Dendrocalamus giganteus) with nominal density of $650 \mathrm{~kg} . \mathrm{m}^{-3}$ and nominal thickness of $12.7 \mathrm{~mm}$. The authors used $10 \%$ UF adhesive and $1.5 \%$ paraffin emulsion. Coarse particles $>1.2 \mathrm{~mm}<4.0 \mathrm{~mm}$ mixed with fine particles $<1.2 \mathrm{~mm}$ (80:20 ratio) were used. The authors obtained mean values for WA2h and WA24h of 15.70 and $48.23 \%$. Nurhazwani et al. (2016) produced homogeneous agglomerated panels using bamboo particles

Table 4. Mean values of water absorption in two hours (WA2h) for granulometry and particle condition.

\begin{tabular}{ccc}
\hline \multirow{2}{*}{ Granulometry } & \multicolumn{2}{c}{ Water absorption (WA2h) (\%) } \\
\cline { 2 - 3 } & \multicolumn{2}{c}{ Particle condition } \\
\cline { 2 - 3 } & Control & Treated \\
\hline $0.50 \mathrm{~mm}$ & $76.52 \mathrm{bB}$ & $64.78 \mathrm{aA}$ \\
$0.85 \mathrm{~mm}$ & $62.22 \mathrm{aA}$ & $63.34 \mathrm{aA}$ \\
\hline
\end{tabular}

Averages followed by the same lowercase letter, in the columns or uppercase letters, in the lines do not differ (F-test, $p>0.05$ ).

Table 5. Mean values of water absorption in two hours (WA24h) for particle granulometry.

\begin{tabular}{cc}
\hline Granulometry $(\mathrm{mm})$ & WA24h $(\%)$ \\
\hline 0.50 & $91.19 \mathrm{~b}$ \\
0.85 & $81.82 \mathrm{a}$ \\
\hline
\end{tabular}

Means followed by the same lowercase letters do not differ (F-test, $p>0.05$ ).
(Dendrocalamus asper) and rubber tree (Hevea brasiliensis) with a particle size of $0.50 \mathrm{~mm}$, isolated and mixed in different proportions. Also, 12\% UF adhesive was used, with a nominal density and thickness of $700 \mathrm{~kg} \cdot \mathrm{m}^{-3}$ and $12 \mathrm{~mm}$, respectively, without the addition of paraffin. The authors found WA24h values of $68.8 \%$. Bazzetto et al. (2019) worked with bamboo particleboards (Dendrocalamus asper) testing four particle sizes. For panels produced with a particle size $0.50 \mathrm{~mm}$ bonded with $10 \%$ UF adhesive, $1 \%$ paraffin emulsion, nominal density $650 \mathrm{~kg} \cdot \mathrm{m}^{-3}$, nominal thickness $15.70 \mathrm{~mm}$ and the same press cycle parameters as those used in the present study obtained $34.3 \%$ and $42.2 \%$ for WA2h and WA24h, respectively.

Table 4 shows the mean thickness swelling values after 2 (TS2h) and 24 (TS24h) hour water immersion and those of the non-recoverable tax (NRT) of the bamboo particleboards. The TS2 $h$ values only showed a significant statistical difference for the particle condition (Table 3).

The average swelling value of the panels comprised of control particles was lower in comparison with those of hotwater treated particles (Table 6), which may be due to the higher volume of treated particles necessary for the mattress, which required a larger amount of woody material (cellular wall) for diffusing the water molecules.

The results are in accordance with Trianoski et al. (2012), who highlighted that extractives can influence the dimensional stability. Both contraction and swelling increase when they are removed from the cellular wall due to the availability of water absorption sites by hydroxilic groupings $\left(\mathrm{OH}^{-}\right)$in the cellulosic material. The particleboards manufactured with control particles showed better performance and lower thickness swelling after 2 hours immersion.

TS24h only showed differences between the factors tested (Table 3). Table 7 shows the test of averages for this property. The $0.85 \mathrm{~mm}$-granulometry revealed an TS24h increment in the particleboards. Boards with $0.50 \mathrm{~mm}$ granulometry were supposedly more compacted in the pressing, which hampered the translocation of water to the cellular walls and promoted lower swelling.

The behavior of TS24h (Table 7) regarding the condition factor was similar to that of TS2h, since the particleboards comprised of treated particles showed an increment in comparison to those constituted of control particles. The same justification can be adopted.

NBR 14810 (ABNT, 2006) establishes an 8\% minimum index for the thickness swelling in a 2 hour immersion for particleboards. The results of the treatments were higher than such a value and did not conform to the norm; it is therefore not recommended to use these panels outdoors without the proper application of a water protection product.

Table 6. Average values for thickness swelling in 2 hours (TS2h) as a function of the particle condition.

\begin{tabular}{cl}
\hline Particle condition & TS2h $(\%)$ \\
\hline Control & $10.45 \mathrm{a}$ \\
Treated & $15.77 \mathrm{~b}$ \\
\hline
\end{tabular}

Means followed by the same letter do not differ (F-test, $p>0.05$ ). 
Table 7. Mean values of thickness swelling in 24 hours (TS24h) for granulometry and particle conditions.

\begin{tabular}{cccc}
\hline $\begin{array}{c}\text { Granulometry } \\
(\mathbf{m m})\end{array}$ & $\begin{array}{c}\text { TS24h } \\
(\mathbf{\%})\end{array}$ & $\begin{array}{c}\text { Particle } \\
\text { condition }\end{array}$ & $\begin{array}{c}\text { TS24H } \\
(\%)\end{array}$ \\
\hline 0.50 & $15.07 \mathrm{a}$ & Control & $12.40 \mathrm{a}$ \\
0.85 & $16.37 \mathrm{~b}$ & Treated & $19.04 \mathrm{~b}$ \\
\hline
\end{tabular}

Means followed by the same letter do not differ (F-test, $p>0.05$ ).

An average value of $12.77 \%$ was obtained for TS2h and $15.72 \%$ for TS24H. The values obtained were higher than those found by Valarelli et al. (2013) which corresponded to $3.0 \%$ and $8.58 \%$.

Nurhazwani et al. (2016) found an average value of 20.1\% for the TS24h, and Bazzetto et al. (2019) obtained 6.7 and $9.3 \%$, respectively. The difference between the values obtained for water absorption and thickness swelling can be explained by the difference between the particle size used, the panel compaction ratio, the variation of some pressing cycle parameter and the moisture content of the mattress.

The NRT values showed a statistical difference only for granulometry and condition of the particles (Table 3). Table 8 shows the test of averages conducted.

The particleboards comprised of $0.50 \mathrm{~mm}$-granulometry particles showed a reduction in the NTS in comparison to those manufactured with $0.85 \mathrm{~mm}$-granulometry particles, which showed a higher residual swelling. Such a result is contrary to what is expected, since the mattresses manufactured with $0.85 \mathrm{~mm}$-granulometry particles show a smaller specific superficial area, which reduces their height in relation to $0.50 \mathrm{~mm}$ particles. The compaction ratio is consequently reduced, which implies a reduction in the compression strain release.

The result may be a consequence of the accommodation of the particles of lower granulometry in the mattress box, since the larger specific superficial area enables fewer empty spaces, which might have resulted in a lower mattress and lower compaction ratio, hence lower NTS.

The NTS average showed a higher percentage increase than double the value obtained for particleboards comprised of control particles. Moreover, the number of particles treated with a smaller density caused by the removal of some extractives in hot water was probably larger and increased both the mattress height and compaction ratio. Higher compression strains were released and the NTS increased.

The vertical density profile values showed a difference for granulometry and particle condition (Table 9).

A significant difference for the apparent specific mass of the external layer was observed in the granulometry and condition of the particles, whereas a significant difference

Table 8. Mean values of non-recoverable thickness swelling (NTS) for granulometry and particle condition.

\begin{tabular}{cccc}
\hline $\begin{array}{c}\text { Granulometry } \\
(\mathbf{m m})\end{array}$ & $\begin{array}{c}\text { NRT } \\
(\%)\end{array}$ & $\begin{array}{c}\text { Particle } \\
\text { condition }\end{array}$ & $\begin{array}{c}\text { NRT } \\
(\%)\end{array}$ \\
\hline 0.50 & $8.80 \mathrm{a}$ & Control & $6.19 \mathrm{a}$ \\
0.85 & $10.23 \mathrm{~b}$ & Treated & $12.84 \mathrm{~b}$ \\
\hline
\end{tabular}

Means followed by the same letter do not differ (F-test, $p>0.05$ ).
Tabela 9. Mean apparent density values of the outer layer $(A D O L)$ and the central layer (ADCL) of the particleboards according to the treatments.

\begin{tabular}{ccc}
\hline Treatments & $\begin{array}{c}\text { ADOL } \\
\left(\mathrm{kg} \mathrm{m}^{-3}\right)^{* *}\end{array}$ & $\begin{array}{c}\mathrm{ADCL} \\
\left(\mathrm{kg} \mathrm{m}^{-3}\right)^{*}\end{array}$ \\
\hline T1 & 481.81 & 549.73 \\
T2 & 596.61 & 608.30 \\
T3 & 489.23 & 558.39 \\
T4 & 546.79 & 582.98 \\
Overall mean & 528.61 & 574.85 \\
CV (\%) & 4.62 & 4.12 \\
\hline
\end{tabular}

CV: coefficient of variation; *A significant factor; ${ }^{* *}$ Two significant factors.

for the central layer was only detected for the particle condition (Table 9). The particleboards comprised of $0.50 \mathrm{~mm}$ granulometry particles showed a higher specific mass value in the external layer (Table 10).

Particles with a larger specific superficial area $(0.50 \mathrm{~mm})$ presumably formed a more compacted arrangement, with no empty spaces and better densification. Particleboards comprised of treated particles showed a higher value than those of control particles regarding condition. The number of treated particles was probably larger for the mattress due to the removal of the extractives. Therefore, the higher number and compaction of the particles resulted in an increase in the apparent specific mass of the external layer.

The particleboards comprised of treated particles showed an increase in the apparent specific mass of the central layer (Table 11). As addressed elsewhere, the higher volume of hotwater-treated particles used in manufacturing the mattress was probably more compacted, which might have increased the apparent specific mass of the layer.

The shape of the apparent density profile of the particleboards is similar to letter " $\mathrm{M}$ " and indicates an oscillation in the specific mass along their thickness. The differences between the peaks of the density profiles and stabilization tendency in the central layer (Figure 3) may be due to the lower compaction rate of the particles in function of density, which resulted in a less thick mattress, hence lower compression strain released.

The particleboards comprised of $0.85 \mathrm{~mm}$ granulometry hot water treated particles (Figure 3D) showed the highest

Table 10. Mean apparent density values of the outer layer (ADOL) for granulometry and particle condition.

\begin{tabular}{cccc}
\hline $\begin{array}{c}\text { Granulometry } \\
(\mathrm{mm})\end{array}$ & $\begin{array}{c}\mathrm{ADOL} \\
\left(\mathrm{kg} \mathrm{m}^{-3}\right)\end{array}$ & $\begin{array}{c}\text { Particle } \\
\text { condition }\end{array}$ & $\begin{array}{c}\mathrm{ADOL} \\
\left(\mathbf{k g ~ m}^{-3}\right)\end{array}$ \\
\hline 0.50 & $539.21 \mathrm{~b}$ & Control & $485.52 \mathrm{a}$ \\
0.85 & $518.01 \mathrm{a}$ & Treated & $571.70 \mathrm{~b}$ \\
\hline
\end{tabular}

Means followed by the same letter do not differ (F-test, $p>0.05$ ).

Table 11. Mean apparent density values of the central layer ( $A D C L)$ for particle condition.

\begin{tabular}{cc}
\hline Particle condition & ADCL $\left(\mathrm{kg} \mathrm{m}^{-3}\right)$ \\
\hline Control & $554.06 \mathrm{a}$ \\
Treated & $595.64 \mathrm{~b}$ \\
\hline
\end{tabular}

Means followed by the same letter do not differ (F-test, $p>0.05$ ). 
A.
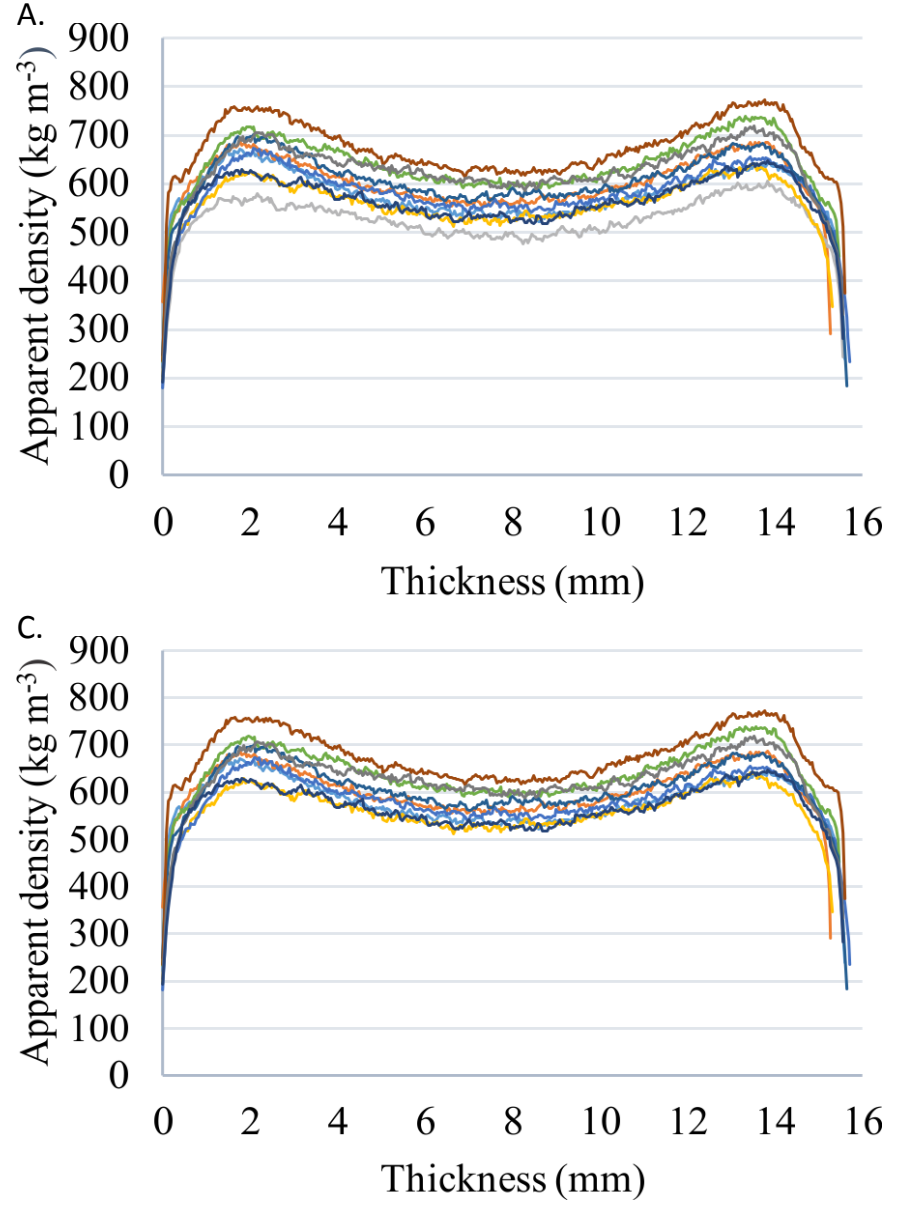
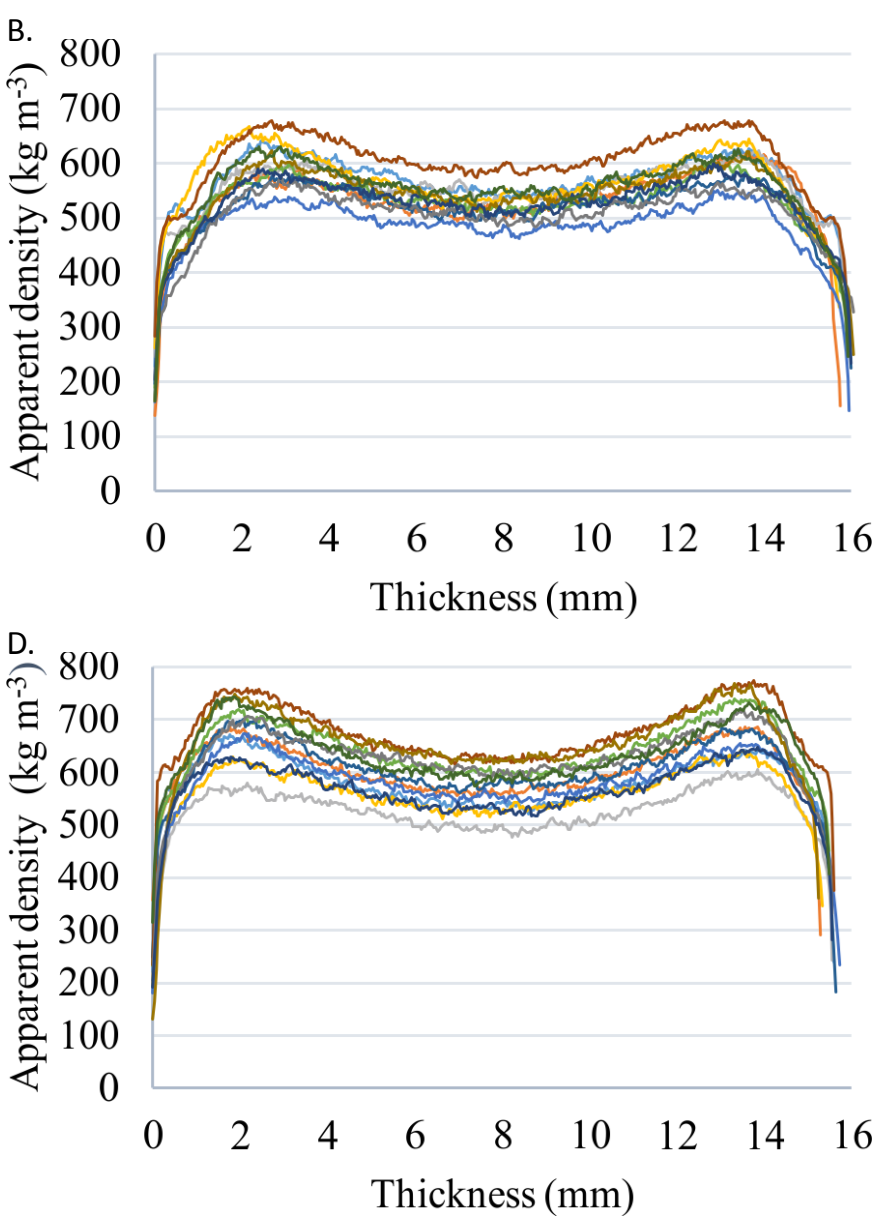

Figure 3. Density profiles of particleboard panels produced with bamboo: (A) Particleboards with a $0.50 \mathrm{~mm}$ granulometry (control); (B) Particleboards with a $0.50 \mathrm{~mm}$ granulometry (treated in hot water); (C) Particleboards with 0.85 mm granulometry (control); (D) Particleboards with a $0.85 \mathrm{~mm}$ granulometry (treated in hot water).

peak of apparent specific mass in the external layer. The higher resistance of the central layer may have influenced the gluing quality of the boards and improved adhesion among the particles.

\section{Mechanical properties of the particleboards}

Table 12 shows the results of the mechanical properties of the bamboo particleboards. No significant difference was observed for the factors and interaction analyzed regarding static bending.

The MOR and MOE (Table 12) results can be explained by the relatively low compaction ratio caused by the specific mass of the bamboo. A relatively small contact area among the particles can increase the relative availability of the adhesive, however it causes a lower amount of adhesive bonding among the particles.

The average value for the MOR of the bamboo particleboards was lower than the minimum value established by NBR 14810 (2006), i.e. $16.0 \mathrm{MPa}$. The value obtained for MOE was below the $1600 \mathrm{MPa}$ established by NBR 14810 (ABNT, 2013).

The mean values obtained for MOR and MOE were lower than those in the literature. Valarelli et al. (2013) found 7.48 MPa and 1.515.55 Mpa for Dendrocalamus giganteus particleboards. Nurhazwani et al. (2016) found values of 15.3 MPa for MOR and $2650 \mathrm{MPa}$ for MOE in homogeneous panels made of $100 \%$ bamboo particles (D. asper). Bazzetto et al. (2019) obtained 7.6 MPa and $981 \mathrm{MPa}$.

Table 12. Mean values of the modulus of rupture (MOR), modulus of elasticity (MOE), surface screw withdrawal (SSW), top screw withdrawal (TSW) and internal adhesion (IA) of particleboards.

\begin{tabular}{cccccc}
\hline Treatments & MOR (MPa) & MOE $(\mathrm{MPa})^{\text {NS }}$ & SSW (N)*** & TSW (N)* & IA (MPa)* \\
\hline T1 & 6.38 & 588.64 & 441.27 & 451.12 & 0.62 \\
T2 & 7.41 & 556.25 & 445.54 & 519.77 & 0.75 \\
T3 & 7.21 & 630.40 & 356.28 & 439.68 & 0.58 \\
T4 & 7.54 & 553.77 & 505.01 & 531.21 & 0.64 \\
Overall mean & 7.14 & 582.26 & 436.77 & 485.45 & 0.65 \\
CV (\%) & 7.77 & 11.04 & 13.00 & 9.78 & 10.63 \\
\hline
\end{tabular}

$\mathrm{CV}$ : coefficient of variation; ${ }^{\text {Ns }}$ Not significant; ${ }^{*} \mathrm{~A}$ significant factor; ${ }^{* * *}$ interaction between factors. 
Although no significant difference was found for MOR, it can be observed (Table 12) that the highest average values came from panels made of particles treated with hot water. This fact is probably related to the larger amount of particles used to form the mattress which were sufficient to avoid forming voids and better distribution of stress during the test, as shown by the values obtained for the density profile (Table 9).

The average SSW and TSW values obtained for the bamboo particleboards (Table 12) were similar due to the vertical density profile of the particleboards (Figure 3), which was not so pronounced and indicated that the specific masses of both faces and core are similar. Such a profile may be related to the mattress height of the particles. Such a situation is uncommon, since the resistance on the face tends to be higher due to the compaction of the external layers. The mean value obtained for IB (Table 12) was lower than that found by Valarelli et al. (2013) corresponding to 0.98 MPa.

A significant difference was observed only for the particle condition (Table 12) and the particleboards comprised of hotwater-treated particles showed the highest SSW, TSW and IA averages (Table 13).

Such values may have been influenced by the removal of extractives, which promoted better polimerization and curing of the adhesive. According to Moslemi (1974), the high content of extractives can negatively affect IA. It is noteworthy that the panels made with treated particles presented the highest value for the central layer of the density profile (Table 11), a fact which may be related to the best result of the internal . Moreover, the higher volume of treated particles, hence a higher compaction ratio in comparison to the non-treated particles may have contributed to the results.

The average values for SSW and TSW of the particleboards (Table 12) did not achieve the minimum values established by NBR 14810 (ABNT, 2006), i.e. $1.020 \mathrm{~N}$ (SSW) and $800 \mathrm{~N}$ (TWS). However, the obtained IA values met the minimum value (0.35 MPa) established.

The values obtained for surface and top screw withdrawal (436.77 $\mathrm{N}$ and $485.45 \mathrm{~N}$ ) were lower than the literature results. Nurhazwani et al. (2016) found $499.9 \mathrm{~N}$ for SSW, while Bazzetto et al. (2019) obtained $706 \mathrm{~N}$ for SSW and found 559 $\mathrm{N}$ for TSW. The average value obtained in the present work for the internal adhesion (0.65 $\mathrm{MPa}$ ) was lower than the result obtained by Valarelli et al. (2013) who found $0.98 \mathrm{MPa}$, but was higher than the values reported by Nurhazwani et al. (2016) corresponding to 0.58MPa, and Bazzetto et al. (2019) who obtained $0.25 \mathrm{MPa}$.

Table 13. Mean values of surface screw withdrawal (SSW), top screw withdrawal (TSW) and internal adhesion (IA) for granulometry and particle condition.

\begin{tabular}{|c|c|c|c|}
\hline \multirow{2}{*}{$\begin{array}{c}\text { Particle } \\
\text { condition }\end{array}$} & SSW & TSW & \multirow{2}{*}{$\begin{array}{c}\text { IA } \\
(\mathrm{MPa})\end{array}$} \\
\hline & \multicolumn{2}{|c|}{ (N) } & \\
\hline Control & $398.77 \mathrm{a}$ & $445.40 \mathrm{a}$ & $0.60 \mathrm{a}$ \\
\hline Treated & $475.27 b$ & $525.49 \mathrm{~b}$ & $0.70 \mathrm{~b}$ \\
\hline
\end{tabular}

Means followed by the same letter do not differ (F-test, $p>0.05$ ).
As mentioned before, the difference between the obtained results and those reported in the literature may be related to particle size, panel compaction ratio, variation of some pressing cycle parameter and mattress moisture content.

\section{Conclusions}

The dimensional stability of the panels was impaired by the particle treatment. The MOR and MOE values were neither influenced by granulometry or particle treatment; however, such a treatment favored the SSW, TSW and IB properties. Higher granulometry particles (i.e. $0.85 \mathrm{~mm}$ ) treated in hot water increased the external layer density. The swelling and mechanical property values, except IB, did not meet the minimum requirements established by the Brazilian norm. Bamboo can be used as an alternative material for particleboard manufacturing as long as its strength characteristics are considered.

\section{Acknowledgements}

This study was financed in part by the Coordenação de Aperfeiçoamento de Pessoal de Nível Superior - Brasil (CAPES) - Finance Code 001. The authors thank the Marcelo Ticelli, Manager of Research and Development Unit, Agronomic Institute of Campinas (IAC), by the donation of bamboo and the SI Group Crios Resinas S.A., by the donation of the adhesive.

\section{Literature Cited}

Abdulkareem, S.A.; Adeniyi, A.G. Production of particleboards using polystyrene and bamboo wastes. Nigerian Journal of Technology, v. 36, n. 3, p. $788-793$, 2017. https://doi.org/10.4314/njt. v36i3.18.

Almeida, A.C.; Araujo, V.A.; Morales, E.A.M.; Gava, M.; Munis, R.A.; Garcia, J.N.; Barbosa, J.C. Wood bamboo particleboard: mechanical properties. Bioresources, v. 12, n. 4, p. 7784-7792, 2017. https://ojs.cnr.ncsu.edu/index.php/BioRes/article/ view/BioRes_12_4_7784_De_Almeida_Wood_Bamboo_ Particleboard/5556. 29 Mar. 2019.

Anokye R.; Bakar, E.S.; Ratnansingam, J.; Awang, K.B. Bamboo properties and suitability as a replacement for wood. Pertanika Journal of Scholarly Research Reviews, v.2, n.1, p. 63-79, 2016. https://pjsrr.upm.edu.my/index.php/pjsrr/article/view/17/16. 20 Mar. 2019.

Associação Brasileira De Normas Técnicas - ABNT. NBR 11941: madeira - determinação da densidade básica. Rio de Janeiro: ABNT, 2003. 6p.

Associação Brasileira De Normas Técnicas - ABNT. NBR 14810: chapas de madeira aglomerada. Parte 3: métodos de ensaio. Rio de Janeiro: ABNT, 2006. 51p.

Associação Brasileira De Normas Técnicas - ABNT. NBR 14810: Painéis de partículas de média densidade. Parte 2: requisitos e métodos de ensaio. Rio de Janeiro: ABNT, 2013. 69p. 
Azambuja, M.A.; Remedio, G.P.; Battistelle, R.A.G.; Silva, S.A.M.; Valarelli, I.D.; Lahr, F.A.R. Granulometric classification of bamboo chips for the production of panels for civil construction. In: Lahr, F.A.R.; Savastano Junior, H.; Fiorelli, J. (Org.). Non-conventional building materials based on agro-industrial wastes. 1.ed. Bauru-SP: Tiliform, 2015. p.103-123. http://www.hu.usp.br/wpcontent/uploads/sites/98/2016/03/Non-conventional-BuildingMaterials_ebook.pdf. 03 Mar. 2019.

Barbirato, G.; Fiorelli, J.; Barrero, N.G.; Pallone, E.M.J.A.; Lahr, F.A.R; Cristoforo, A. L.; Savastano Junior, H. Painel aglomerado híbrido de casca de amendoim reforçado com partículas de madeira itaúba. Ciência Florestal, v. 24, n. 3, p. 685-697, 2014. https://doi. org/10.5902/1980509815726.

Bazzetto, J. T. L.; Bortoletto Junior, G.; Brito, F.M.S. Effect of particle size on bamboo particle board properties. Floresta Ambiente, v.26, n.2, 2019. https://doi.org/10.1590/2179-8087.012517.

Beraldo, A. L.; Azzini, A. Bambu: características e aplicações. Guaíba: Livraria Editora Agropecuária, 2004. 180p.

Berndsen, R. S.; Klitzke, R. J.; Batista, D. C.; Nascimento, E. M.; Ostapiv, F. Propriedades físicas do bambu-mossô (Phyllostachys pubescens) em diferentes idades e posições do tronco. Floresta, v. 40, n.1, p. 183-192, 2010. https://doi.org/10.5380/ rf.v40i1.17109.

Brito, F.M.S. Produção e avaliação da qualidade de painéis aglomerados constituídos por partículas de bagaço de canade-açúcar e bambu. Piracicaba: Escola Superior de Agricultura Luiz de Queiroz, 2018. 214 p. Tese Doutorado. https://doi. org/10.11606/T.11.2018.tde-03052018-132019.

Brito, F.M.S.; Paes. J.B.; Oliveira. J.T.S.; Arantes. M.D.C.; Vidaurre, G.B.; Brocco. V. F. Physico-mechanical characterization of heattreated glued laminated bamboo. Construction and Building Materials, v. 190, p. 719-727, 2018. https://doi.org/10.1016/j. conbuildmat.2018.09.057.

Cai, Z.; Muehl, J. H.; Winandy, J. Effects of press schedule on formation of vertical density profile for MDF panels. In: International Wood Composites Symposium, 40., 2006, Seattle. Proceedings... Washington: Washington State University, 2006. https://www. fpl.fs.fed.us/documnts/pdf2006/fpl_2006_cai003.pdf. 12 Aug. 2019.

Chaowana, P. Bamboo: an alternative raw material for wood and wood-based composites. Journal of Materials Science Research, v. 2, n. 2, 2013. http://dx.doi.org/10.5539/jmsr.v2n2p90.

Clark, L. G.; Londono, X.; Ruiz-Sanchez, E. Bamboo taxonomy and habitat. In: Liese, W.; Kohl, M. (Eds.). Bamboo: the plant and its uses. Cham: Springer International Publishing, 2015. Chap 1, p.130. (Tropical Forestry, 10). https://doi.org/10.1007/978-3-31914133-6_1.

Dinhane, F.C.R.; Araújo, I.I.; Valarelli, I. D.; Bueno, M.A.P.; Ferreira, B. S.; Campos, C. I. Particleboard manufactured with bamboo and coconut fibers in different ratios of adhesive. Advanced Materials Research, v. 1088, p. 672-675, 2015. https://doi.org/10.4028/ www.scientific.net/AMR.1088.672.

Farrokhpayam, S.R.; Valadbeygi, T.; Sanei E. Thin particleboard quality: effect of particle size on the properties of the panel. Journal of Indian Academy of Wood Science, v.13, n. 1, p. 38-43, 2016. https://doi.org/10.1007/s13196-016-0163-9.
Fazita, M.R.N.; Jayaraman, K.; Bhattacharyya, D.; Haafiz , M.K.M.; Saurabh, C.K.; Hussin, M.H.; AKH, P.S. Green composites made of bamboo fabric and poly (lactic) acid for packaging applications - a review. Materials, v. 9, n. 6, article 435, 2016. https://doi. org/10.3390/ma9060435.

Indústria Brasileira de Árvores - IBÁ. Setor de árvores plantadas. Brasília: IBÁ, 2018. 6p.

Iwakiri, S.; Trianoski, R.; Azambuja, R.R.; Ribeiro, R.S. Produção de painéis aglomerados com misturas de seis espécies de madeiras da amazônia e Pinus taeda. Floresta, v. 46, n. 2, p. 259 - 267, 2016. https://doi.org/10.5380/rf.v46i2.40866.

Klímek, P., Wimmer, R., Meinlschmidt, P., Kúdela, J. Utilizing Miscanthus stalks as raw material for particleboards. Industrial Crops and Products, v. 111, p. 270-276, 2018. https://doi. org/10.1016/j.indcrop.2017.10.032.

Lias, H.;Kasin, J.;Johari, N.A.N.;Moktar, I.L.M.Influence ofboarddensity and particle sizes on the homogeneous particleboard properties from kelempayan (Neolamarckia cadamba). International Journal of Latest Research in Science and Technology, v. 3, n. 6, p. 173-176, 2014. https://pdfs.semanticscholar.org/ae70/ e5de552e170cf9543a0ef38d0cc56b15db20.pdf. 12 Aug. 2019.

Maloney, T.M. Modern particleboard \& dry-process fiberboard manufacturing. San Francisco: Miller Freeman Publication, 1993. $689 \mathrm{p}$.

Melo, R.R.; Stangerlin, D.M.; Sousa, A.P.; Cademartori, P.H.G.; Schneid, E. Propriedades físico-mecânicas de painéis aglomerados madeira-bambu. Ciência Rural, v.45, n.1, p.35-42, 2015. https:// doi.org/10.1590/0103-8478cr20120970.

Mesquita, A. L.; Barrero, N.G.; Fiorelli, J.; Christoforo, A.L.; Faria, L.J.G.; Lahr, F.A.R. Eco-particleboard manufactured from chemically treated fibrous vascular tissue of acai (Euterpe oleracea Mart.) Fruit: a new alternative for the particleboard industry with its potential application in civil construction and furniture. Industrial Crops and Products, v.112, p. 644-65, 2018. https://doi.org/10.1016/j.indcrop.2017.12.074.

Morais, W.W.C.; Haselein, C.R.; Susin, F.; Vivian, M.A.; Morais, J.B.F. Propriedades físico-mecânicas de painéis aglomerados com Bambusa tuldoides e Pinus taeda. Ciência Florestal, v. 25, n. 4, p. 1015-1026, 2015. https://doi.org/10.5902/1980509820662.

Moslemi, A.A. Particleboard. London: Southern Illinois University Press, 1974. 244p.

Negrão, W. H.; Silva, S.A.M.; Christoforo, A.L.; Lahr, F.A.R. Painéis aglomerados fabricados com mistura de partículas de madeiras tropicais. Ambiente Construído, v.14, n.3, p. 103-112, 2014. https://doi.org/10.1590/S1678-86212014000300008.

Nogueira, I.M.S.; Lahr, F.A.R.; Giacon, V.M. Desenvolvimento e caracterização de painéis de partículas aglomeradas utilizando o resíduo do ouriço da Castanha-do-Brasil (Bertholletia excelsa) e resina poliuretana derivada do óleo da mamona. Revista Matéria, v.23, n.1, e-11985, 2018. https://doi.org/10.1590/ s1517-707620170001.0321.

Nurhazwani, O.; Jawaid, M.; Paridah, M.T.; Abdul, J.H.; Hamid, S.A.; Hybrid particleboard from bamboo (Dendrocalamus asper) veneer waste and rubberwood (Hevea brasiliensis). BioResources, v.11, n.1, p. 306-323, 2016. https://doi. org/10.15376/biores.11.1.306-323. 
Sanquetta, C.R.; Ruza, M.S.; Corte, A.P.D.; Mognon, F.; Behling, A. Estimativa de volume aparente do colmo de três espécies de bambus exóticos. In: Drumond, P. M; Wiedman, G. (Orgs.). Bambus no Brasil: da biologia à tecnologia. 1.ed. Rio de Janeiro: $\mathrm{ICH}$, 2017. p. 60-70. http://ainfo.cnptia.embrapa.br/digital/ bitstream/item/165714/1/26392.pdf. 02 Aug. 2019.

Santos, D.R.S.; Sette Junior, C.R.; Silva, M.F.; Yamaji, F. M.; Almeida, R.A. Potencial de espécies de bambu como fonte energética. Scientia Forestalis, v. 44, n. 111, p. 751-758, 2016. https://doi. org/10.18671/scifor.v44n111.21.

Surdi, P.G.; Bortoletto Junior, G.; Castro, V.R.; Mendes, R.F.; Almeida; N.F.; Tomazello Filho, M. Relação entre perfil de densidade e ligação interna de painéis OSB de Pinus spp. Floresta e Ambiente, v. 21 , n. 3, p. 349-357, 2014. https://doi.org/10.1590/21798087.063413.

Tombolato, A.F.C.; Greco, T.M.; Pinto, M.M. Dez espécies de bambus exóticos mais comuns no paisagismo no Brasil. Revista Brasileira de Horticultura Ornamental, v. 18, n. 2, p. 105-114, 2012. https://ornamentalhorticulture.emnuvens.com.br/rbho/article/ download/687/497. 22 out 2016.

Torrell, R.; Hillig, E.; Corradi, G.M.; Iwakiri, S. Influência da adição de serragem nas propriedades tecnológicas de painéis de madeira aglomerada de Pinus taeda. Ambiência, v. 9, n. 1, p. 57-72, 2013. https://doi.org/10.5777/ambiencia.2013.01.04.
Trianoski, R.; Matos, J.L.M.; Iwakiri, S.; Prata, J.G. Avaliação da Estabilidade Dimensional de Espécies de Pinus Tropicais. Floresta e Ambiente, v. 20, n.3, p.398-406, 2012. https://doi.org/10.4322/ floram.2012.071.

Valarelli, I.D.; Azambuja, M.A.; Bastistelli, R.A.G.; Campos, C.I. Avaliação do desempenho de painéis de partículas aglomeradas de bambu da espécie Dendrocalamus giganteus. In: Lahr, F.A.R.; Christoforo, A.L. (Org.). Painéis de partículas de madeira e materiais lignocelulósicos. São Carlos: EESC/USP, 2013. p. 179-213. https:// www.researchgate.net/publication/272678794. 10 Aug. 2019.

Valarelli, I.D.; Battistelle, R.A.G.; Bueno, M.A.P.; Bezerra, B.S.; Campos, C.I.; Alves, M.C.S. Physical and mechanical properties of particleboard bamboo waste bonded with urea formaldehyde and castor oil based adhesive. Revista Matéria, v.19, n. 1, p.1-6, 2014. https://doi.org/10.1590/S1517-70762014000100002.

Wang, X.; Mohammad, M.; Hu, L.J.; Salenikovich, A. Evaluation of density distribution in wood-based panels using X-ray scanning. Journal of Nondestructive Testing, v. 11, n.4, 2006. https://www. ndt.net/article/v11n04/wang/wang.htm. 13 Aug. 2019.

Zaia, U.J.; Cortez-Barbosa, J.; Morales, E.A.M.; Lahr, F.A.R.; Nascimento, M.F.; Araújo, V.A. Production of particleboards with bamboo (Dendrocalamus giganteus) Reinforcement. Bioresources, v. 10, n. 1, p. 1424-1433, 2015. https://doi. org/10.15376/biores.10.1.1424-1433. 